\title{
Anti-inflammatory activity of Heterotheca subaxillaris var. latifolia (Buckley) Gandhi \& R.D. Thomas, Asteraceae
}

\author{
Susana Gorzalczany, ${ }^{1}$ Maria A. Rosella, ${ }^{2}$ Etile D. Spegazzini, ${ }^{2}$ Cristina Acevedo, ${ }^{1}$ \\ Silvia L. Debenedetti*,2,3
}

\author{
${ }^{1}$ Cátedra de Farmacología, Facultad de Farmacia y Bioquímica, Universidad de Buenos Aires, Junín 956, \\ 1113 Buenos Aires, Argentina \\ ${ }^{2}$ Cátedra de Farmacognosia y Cátedra de Farmacobotánica, Facultad de Ciencias Exactas, \\ Universidad Nacional de La Plata, Calle 47 y 115, 1900 La Plata, Argentina \\ ${ }^{3}$ Cátedra de Farmacognosia y Fitoquímica, Facultad de Ciencias Exactas y Naturales, Universidad de Belgrano, \\ Villanueva 1324, 1426 Ciudad Autónoma de Buenos Aires, Argentina
}

\begin{abstract}
RESUMO: “Atividade antiinflamatória de Heterotheca subaxillaris var. latifolia (Buckley) Gandhi \& R.D. Thomas (Asteraceae)". A atividade antiinflamatória de extratos éter petróleo, diclorometânico e metanólico de Heterotheca subaxillaris var. latifolia, foi testada pelo método de edema induzido pelo 12-O-tetradecanoil phorbol acetato (TPA) na orelha do camundongos e pelo método do edema de pata induzido por carragenina em ratos. $\mathrm{O}$ extrato diclorometânico mostrou atividade antiinflamatória significativa ( $91 \%$ inibição) no edema de orelha induzido por TPA (administração tópica de $1 \mathrm{mg}$ /orelha). Não houve efeitos significativos no teste do edema induzido pela carragenina. O fracionamento bioguiado das frações ativas levou ao isolamento dos flavonoides majoritários santina, pectolinaringenina, 3,6-dimetoxi-5, 7,4 '-trihidroxiflavona e hispidulina.
\end{abstract}

Unitermos: Heterotheca subaxillaris var. latifolia, Asteraceae, atividade antiinflamatória, flavonoides.

\begin{abstract}
The anti-inflammatory activity of the petroleum ether, dichloromethane and methanol extracts from Heterotheca subaxillaris var. latifolia were assayed using 12-O-tetradecanoyl phorbol acetate (TPA) induced ear edema test in mice and carrageenan-induced paw edema test in rats. The dichloromethane extract showed a significant anti-inflammatory activity ( $91 \%$ of inhibition) in TPA-induced ear edema test (topical administration at $1 \mathrm{mg} /$ ear). No effects were seen on carragenan-induced edema. Bio-guided fractionation deal to the isolation of the major flavonoids santin, pectolinaringenin, 3,6-dimethoxy-5,7,4'-trihydroxyflavone and hispidulin present in the active fractions.
\end{abstract}

Keywords: Heterotheca subaxillaris var. latifolia, Asteraceae, anti-inflammatory activity, flavonoids.

\section{INTRODUCTION}

Heterotheca subaxillaris var. latifolia (Buckley) Gandhi \& R.D. Thomas, Asteraceae, is a weed widely distributed in the north western and central regions of Argentina. It is locally known as "alcanfor" because of its aromatic odour. It is also known in Mexico, where the infusion of the entire plant is used orally by the Kickapoo Indians to ease menstrual pains (Latorre \& Latorre, 1977).

Previous phytochemical screening has described the isolation of terpene derivatives from $H$. latifolia (Bohlmann etal., 1980; Bohlmann etal., 1985). Recently, we described the isolation and identification of five flavonoids from this species (Rojo et al., 2004). The composition of the essential oil from the leaves and flowers has also been evaluated (Lincoln \& Lawrence, 1984; Bandoni et al., 1986; Duschatzky et al., 1998). Essential oil obtained from $H$. latifolia of San Luis Province, Argentina, was found to inhibit Junin virus (García et al., 2003). However, there are no data in the literature concerning the possible pharmacological effects and the active constituents of this plant.

In this study, different extracts from the aerial parts of $H$. subaxillaris var. latifolia and the fractions obtained from dichloromethane extract were tested for their anti- 
inflammatory activity. Isolation of santin, pectolinaringenin, 3,6-dimethoxy-5,7,4'-trihydroxyflavone and hispidulin from the active fractions are reported.

\section{MATERIAL AND METHODS}

\section{Plant material}

Aerial parts of Heterotheca subaxillaris var. latifolia (Buckley) Gandhi \& R.D. Thomas were collected from San Luis Province (Argentine). A voucher specimen was deposited at the Museum ofBotany and Pharmacognosy "Carlos Spegazzini", Faculty of Exact Sciences, National University of La Plata, (LPE 927).

\section{Preparation of extracts}

Air-dried and powered plant $(500 \mathrm{~g})$ was successively macerated with petroleum ether (60-80 ${ }^{\circ}$ ), $\mathrm{CH}_{2} \mathrm{Cl}_{2}$ and $\mathrm{MeOH}$ for $48 \mathrm{~h}$ at room temperature. By removing the solvents in vacuo, crude extracts of increasing polarity were obtained (3.1, 7.8 and 60.9 g respectively).<smiles>COc1ccc(-c2oc3cc(O)c(OC)c(O)c3c(=O)c2OC)cc1</smiles><smiles>COc1c(O)cc2oc(-c3ccc(O)cc3)c(OC)c(=O)c2c1O</smiles>

3

\section{Animals}

Male Wistar rats (150-200 g) and male Swiss mice (25-30 g) were used taking into account international principles and local regulations concerning the care and use of laboratory animals (Olfert et al., 1993). The animals were housed in standard environmental conditions $(25 \pm 1$ ${ }^{\circ} \mathrm{C}$, with a $12 \mathrm{~h}$ light/dark cycle) with free access to a standard commercial diet and water ad libitum.

\section{Fractionation of active extract}

The active $\mathrm{CH}_{2} \mathrm{Cl}_{2}$ extract (1.9 g) was submitted to chromatografic columnn on Sephadex ${ }^{\circledR}$ LH20 (2.5 x 60 $\mathrm{cm})$ eluted with $\mathrm{CHCl}_{3}(500 \mathrm{~mL}), \mathrm{CHCl}_{3}: \mathrm{MeOH}(1: 1)$ (500 $\mathrm{mL})$ and $\mathrm{MeOH}(500 \mathrm{~mL})$. Five fractions: CI (650 mg, 25$250 \mathrm{~mL}$ ), CII (415 mg, 250-500 mL), CMI (364 mg, 500$750 \mathrm{~mL}$ ), CMII (297 mg, 750-1000 mL) and MI (96 mg, 1000-1500 mL) were obtained. Fraction MI was obtained in small quantity and its activity could not be assessed.

\section{Isolation and identification}

Active fractions CMI and CMII were chromatographed on preparative Silicagel 60 plate using toluene:EtOAc (7:3) as mobile phase to give 3,6,4'trimethoxy-5,7-dihydroxyflavone (santin) (1) and 6,4'dimethoxy-5,7-dihydroxyflavone (pectolinaringenin) (2) from fraction CMI and 3,6-dimethoxy-5,7,4'trihydroxyflavone (3) and 6-dimethoxy-5,7, $4^{\prime}$ trihydroxyflavone (hispidulin) (4) from fraction CMII. The structures of the isolated flavonoids (1-4) were determined on the basis of spectral data (UV, MS, ${ }^{1} \mathrm{H}$ and ${ }^{13} \mathrm{C} \mathrm{NMR}$ ) and in comparison with authentical samples (Rojo et al., 2004).<smiles>COc1ccc(-c2cc(=O)c3c(O)c(OC)c(O)cc3o2)cc1</smiles>

2<smiles>COc1c(O)cc2oc(-c3ccc(O)cc3)cc(=O)c2c1O</smiles>

\section{Anti-inflamatory evaluation}

\section{TPA-induced ear edema in mice}

Ear edema was induced according to Carlsson et al. (1989). Groups of ten animals each were used. The right ear of each mouse received a topical application of $2.5 \mu \mathrm{g}$ of $12-O$-tetradecanoylphorbol-13 acetate (TPA) in $20 \mu \mathrm{L}$ acetone $(10 \mu \mathrm{L}$ to each side of the ear).

Petroleum ether, $\mathrm{MeOH}, \mathrm{CH}_{2} \mathrm{Cl}_{2}$ extracts and fractions CI, CII, CMI and CMII (dissolved in EtOH 80\%), 
were applied topically immediately after TPA at the dose of $1 \mathrm{mg} /$ ear. Left ear, used as control, received the vehicle. Indomethacin $(0.5 \mathrm{mg} / \mathrm{ear})$ was used as reference drug. After $4 \mathrm{~h}$, animals were sacrificed by cervical dislocation. Disks of $6 \mathrm{~mm}$ diameter were removed from each ear and the weight was determined. The swelling was measured as the difference in weight between the punches from right and left ears, and expressed as an increase in ear thickness.

\section{Carrageenan-induced edema in rats}

Groups of five animals each were used. Paw swelling was elicited with $0.1 \mathrm{~mL} 2 \%$ carrageenan in $0.9 \%$ saline $(\mathrm{w} / \mathrm{v})$ injected in the right hind paw under the plantar aponeurosis (Winter et al., 1962). Petroleum ether, $\mathrm{MeOH}$ and $\mathrm{CH}_{2} \mathrm{Cl}_{2}$ extracts and fractions CI, CII, CMI CMII (200 $\mathrm{mg} / \mathrm{kg}$ ) dissolved in EtOH-Tween 80-water 5:5:90 and the reference drug indomethacin $(10 \mathrm{mg} / \mathrm{kg})$ were administered orally $1 \mathrm{~h}$ before carrageenan injection. A control group received the vehicle only $(5 \mathrm{~mL} / \mathrm{kg})$. The inflammation was quantified by measuring the volume displaced by the paw, using a plethysmometer (Ugo Basile) at time 0 and 1,3 , and $5 \mathrm{~h}$ after carrageenan injection. The difference between the left and the right paw volumes (indicating the degree of inflammation) was determined and the percent inhibition of edema was calculated in comparison to the control animals.

\section{Statistical analysis}

Results are expressed as mean \pm SEM. Differences between the control and treated groups were tested for significance using a one-way analysis of variance (ANOVA), followed by Dunnett's $t$-test. P values $<0.05$ were considered to be significant.

\section{RESULTS AND DISCUSSION}

Petroleum ether, dichloromethane and methanol extracts obtained from the aerial parts of Heterotheca subaxillaris var. latifolia (Buckley) Gandhi \& R.D. Thomas, where tested in two models of inflammation, TPA-induced ear edema in mice (topical administration at $1 \mathrm{mg} / \mathrm{ear}$ ) and carrageenan induced paw edema in rats (oral administration of $200 \mathrm{mg} / \mathrm{kg}$ ) giving different results. This could be due to the mechanism of the phlogistic agents and/or the administration way used.

The dichloromethane extract, when applied at the dose of $1 \mathrm{mg} / \mathrm{ear}$, exerted a $91 \%$ inhibition of the TPA-ear edema, whereas petroleum ether, and methanol extracts did not show any significant anti-inflammatory activity (Table 1).

Chromatographic fractionation of the $\mathrm{CH}_{2} \mathrm{Cl}_{2}$ extract yielded five fractions and four of them (CI, CII, CMI, CMII) were tested under the same experimental conditions.

All dichloromethane fractions assayed were capable to inhibit significantly the development of TPAinduce ear edema, being the major active fractions CMI and CMII with inhibition of 77.33 and $90.42 \%$ respectively. These values were greater than those produced by $0.5 \mathrm{mg} /$ $\mathrm{kg}$ of indomethacin (Table 1). Four flavonoides, santin (1), pectolinaringenin (2) from fraction CMI and 3,6dimethoxy-5,7,4'-trihydroxyflavone (3) and hispidulin (4) from CMII were isolated and identified as the major constituents of the active fractions.

The results obtained in the carragenan-induced paw edema are shown in Table 2. It should be noted that petroleum ether, methanolic and dichloromethane extracts $(200 \mathrm{mg} / \mathrm{kg}$ p.o.) were inactive. Only fraction CII induced a moderate but significant inhibition of paw-swelling of 50 and $40 \%$ at 3 and $5 \mathrm{~h}$ respectively, while indomethacin (10 $\mathrm{mg} / \mathrm{kg}$ p.o.) showed a marked inhibitory effect of 70 and $62 \%$ at the same times.

Topical administration of TPA provides a skin inflammation model suitable for the evaluation of topical and systemic anti-inflammatory agents, besides providing some information of the mechanism involved. TPA binds and activates the protein kinase $\mathrm{C}$ (PKC) by interaction at the diacylglycerol site, inducing a pronounced inflammatory response. PKC is a $\mathrm{Ca}^{++}$and phospholipid-dependent protein kinase which is present in one of the earliest events in the cascade of signal transduction pathways leading to a variety of cellular responses such as secretion, gene expression, cellular proliferation, cellular differentiation and muscle contraction. This enzyme is related to the pathogenesis of inflammation with phospholipase A2dependent arachidonic acid release and eicosanoid production (Castagna et al., 1982; Nishizuka, 1984, 1988) and many natural flavonoids have been reported to inhibit PKC (Ferriola et al., 1989; Argullo et al., 1997). Therefore, the antiinflammatory activity showed by dichloromethane extract and fractions on the TPA-mouse ear model could be mediated by the inhibition of this enzyme. On the other hand, flavonoids may inhibit the cyclo-oxygenase and/or the 5-lipoxygenase pathways of arachidonate metabolism.

Williams et al. (1995) described that the flavonoid tanetin, which structure was revised to santin (Wiliams et al., 1999), inhibited both enzymes with similar potency when using rat leukocytes activated by the calcium ionophore A. 3,6-dimethoxy-5,7,4'-trihydroxyflavone, gave a similar enzyme profile to santin, shown to be active against acute inflammation in mice induced by TPA (12$O$-tetradecanoylphorbol acetate) (Recio et al., 1995). Therefore, the isolation and identification of compounds with anti-inflammatory effects as santin, 3,6-dimethoxy5,7,4'-trihydroxyflavone and hispidulin (Gil et al., 1994) as well as other related flavonoids as pectolinaringenin from fraction CMI and CMII could justify the observed anti-inflammatory activity. 
Table 1. Topical anti-inflammatory activity of the extracts and $\mathrm{CH}_{2} \mathrm{Cl}_{2}$ fractions of Heterotheca subaxillaris var. latifolia in 12$O$-tetradecanoylphorbol acetate-induced ear edema in mice.

\begin{tabular}{lccc}
\hline \multicolumn{1}{c}{ Treatment } & $\begin{array}{c}\text { Dose } \\
(\mathrm{mg} / \text { ear })\end{array}$ & Edema $(\mathrm{mg})^{\mathrm{a}}$ & Inhibition (\%) \\
\hline Control & ------ & $11.69 \pm 0.43$ & ---- \\
Petroleum ether & 1 & $9.33 \pm 0.36$ & 20.19 \\
$\mathrm{CH}_{2} \mathrm{OH}$ & 1 & $8.56 \pm 0.54$ & 26.77 \\
$\mathrm{CH}_{2} \mathrm{Cl}_{2}$ & 1 & $1.21 \pm 0.25^{*}$ & 91.11 \\
Fraction CI & 1 & $5.16 \pm 0.70^{*}$ & 55.86 \\
Fraction CII & 1 & $5.20 \pm 0.76^{*}$ & 55.52 \\
Fraction CMI & 1 & $2.65 \pm 0.62 *$ & 77.33 \\
Fraction CMII & 1 & $1.12 \pm 0.33^{*}$ & 90.42 \\
Indomethacin & 0.5 & $3.48 \pm 0.59^{*}$ & 70.23 \\
\hline
\end{tabular}

${ }^{\mathrm{a}}$ Values are mean $\pm \mathrm{SEM}, \mathrm{n}=10 ; * \mathrm{P}<0.01$ vs. control, Dunnett's test.

Table 2. Oral anti-inflammatory activity of Heterotheca subaxillaris var. latifolia extracts and $\mathrm{CH}_{2} \mathrm{Cl}_{2}$ fractions on carrageenan induced paw edema in rats.

\begin{tabular}{lcccc}
\hline \multirow{2}{*}{ Treatment } & Dose & \multicolumn{3}{c}{ Edema volume $(\mathrm{mL})$} \\
\cline { 3 - 5 } & $\mathrm{mg} / \mathrm{kg}$ p.o. & $1 \mathrm{~h}$ & $3 \mathrm{~h}$ & $5 \mathrm{~h}$ \\
\hline Control & --- & $0.23 \pm 0.07$ & $1.73 \pm 0.25$ & $2.25 \pm 0.23$ \\
Petroleum ether & 200 & $0.22 \pm 0.06$ & $1.68 \pm 0.31$ & $2.12 \pm 0.21$ \\
$\mathrm{CH}_{2} \mathrm{OH}$ & 200 & $0.25 \pm 0.04$ & $1.71 \pm 0.22$ & $2.09 \pm 0.26$ \\
$\mathrm{CH}_{2} \mathrm{Cl}_{2}$ & 200 & $0.26 \pm 0.06$ & $1.62 \pm 0.23$ & $2.05 \pm 0.22$ \\
Fraction C I & 200 & $0.22 \pm 0.05$ & $1.86 \pm 0.26$ & $2.28 \pm 0.17$ \\
Fraction C II & 200 & $0.16 \pm 0.06$ & $0.86 \pm 0.32^{*}$ & $1.35 \pm 0.24^{*}$ \\
Fraction CM I & 200 & $0.21 \pm 0.07$ & $1.50 \pm 0.14$ & $1.97 \pm 0.14$ \\
Fraction CM II & 200 & $0.23 \pm 0.06$ & $2.14 \pm 0.17$ & $2.37 \pm 0.16$ \\
Indomethacin & 10 & $0.16 \pm 0.03$ & $0.52 \pm 0.22^{*}$ & $1.09 \pm 0.27 *$ \\
\hline Valus a mean
\end{tabular}

Values are mean $\pm \mathrm{SEM}, \mathrm{n}=5 ; * \mathrm{P}<0.05$ vs. control, Dunnett's test.

\section{ACKNOWLEDGEMENTS}

This work was supported in part by SECYTUNLP X446 and SECYT-UBA.

\section{REFERENCES}

Argullo G, Gamet-Payrastre L, Manenti S, Viala C, Rémésy C, Chap H, Payrastre B 1997. Relationship between flavonoid structure and inhibition of phosphatidylinositol 3-kinase: a comparison with tyrosine kinase and protein kinase C inhibition. Biochem Pharmacol 53: 1649-1657.

Bandoni L, Grassetti C, Perina R 1986. Essential oil of Heterotheca latifolia. Perfum Flavor 11: 67-68.

Bohlmann F, Gupta RD, King RM, Robinson H 1980. New cadinene derivatives from Heterotheca latifolia. Phytochemistry 21: 2982-2984.

Bohlmann F, Wolfrum C, Jakupovic J, King RM, Robinson H 1985. Further cadinene derivatives from Heterotheca latifolia. Phytochemistry 24: 1101-1103.
Carlson RP, O'Neill-Davis L, Calhoun W, Datko L, Musser J, Kreft A, Chang J 1989. Effect of 5-lipoxygenase (5-LO)/ cyclooxygenase (CO) inhibitor, WY-47,288 on cutaneous models of inflammation. Agents Actions 26: 319-328.

Castagna M, Takai Y, Kaibuchi K, Sano K, Kakkawa U, Nishizuka YJ 1982. Direct activation of calcium activated phospholipid-dependent protein kinase by tumorpromoting phorbol esters. J Biol Chem 57: 7847-7851.

Duschatzky C, Carrascull A, Bailac P, Ponzi M, Van Baren C, Muschietti L, Coussio JD 1998. Composition of the essential oil from flowers and leaves of Heterotheca latifolia Buckley (Compositae). J Essent Oil Res 10: 101-103.

Ferriola P, Cody V, Middleton E 1989. Protein kinase C inhibition by plant flavonoids. Biochem Pharmacol 38: 1617-1624.

García CC, Talarico L, Almeida N, Colombres S, Duschatzky C, Damonte EB 2003. Virucidal activity of essential oils from aromatic plants of San Luis, Argentina. Phytother Res 17: 1073-5.

Gil B, Sanz MJ, Terencio MC, Ferrandiz ML, Bustos G, Paya M, Gunasegaran R, Alcaraz MJ 1994. Effects of flavonoids on Naja Naja and human recombinant synovial phospholipases A2 and inflammatory responses in mice. Life Sci 54: 333-338.

Latorre DI, Latorre FA 1977. Plants used by the Mexican Kickapoo Indians. Econ Bot 3: 340-357.

Lincoln DE, Lawrence BM 1984. The volatile constituents of camphorweed, Heterotheca subaxillaris. Phytochemistry 23: 933-934.

Nishizuka Y 1984. The role of protein kinase C in cell surface signal transduction and tumour. Nature 308: 693-696.

Nishizuka Y 1988. The molecular heterogeneity of protein kinase $\mathrm{C}$ and its implications for cellular regulation. Nature 334: 661-665.

Olfert ED, Cross BM, McWilliam AA 1993. Canadian council of animal care guide to the care and use of experimental animals Vol.1, 2a. ed.

Recio MC, Giner RM, Mañez S, Talens A, Cubells L, Guebo J, Julien HR, Hostettman K, Rios JL 1995. Antiinflammatory activity of flavonol glycosides from Erythrospermum monticolum depending on single or repeated local TPA administration. Planta Med 61: 502504.

Rojo A, Palacios P, Acevedo C, Spegazzini E, Debenedetti S 2004. 6-Methoxyflavonoids from Heterotheca latifolia (Asteraceae). Biochem Syst Ecol 32: 351-353.

Williams CA, Hoult JRS, Harborne JB, Greenham J, Eagles J 1995. A biologically active lipophilic flavonoid from Tanacetum parthenium. Phytochemistry 38: 267-270.

Williams CA, Harborne JB, Geiger H, Hoult JRS 1999. The favonoids of Tanacetum parthenium and T. vulgare and their anti-inflammatory properties. Phytochemistry 51: 417-423.

Winter CA, Risley EA, Nuss GN 1962. Carragenin-induced edema in hind paw of the rat as an assay for anti-inflammatory drugs. Proc Soc Exp Biol Med 111: 544-547. 